\title{
Urban Growth in Sustainability Perspective
}

\author{
Ayse Nur Albayrak and Yasasin Eryilmaz
}

\begin{abstract}
The growth of cities is the most important factor effecting natural lands. Sustainable urban development strategies try to find solutions for less natural resource consumption and minimum use of urban areas while the cities sustain their economic developments. In this study, different urban growth types have been reviewed in terms of sustainable urban development. The focus of the study is Gebze, an industrial settlement in the periphery of Istanbul Metropolitan Area, Turkey. Examination made on urban form in Gebze indicates that different urban growth types have been determinant in historical process.
\end{abstract}

Keywords-Gebze, sustainable urban development, urban growth

\section{INTRODUCTION}

A gradually larger proportion of world population has begun to live in cities. In this urbanization process starting with industrial revolution, social and economic difficulties occur for those living in city, on the one hand, while the growth of cities becomes fact at the cost of loss of natural areas and environmental values, on the other hand. Having become a frequently used term from $80 \mathrm{~s}$, sustainability represents to establish a consensus ground among environmental, economic and social dimensions of urbanization and industrialization.

Sustainability, in its most common definition, is defined as "meeting the requirements of today without remaining insensitive to the capability of meeting the requirements of next generations" [1]. This approach directs strategies and policies in a wide range of fields such as industry, agriculture, energy. In this context, it is important that civic improvements take place within a sustainable approach, as well.

Having initially been discussed on the basis of polluting effects of industry and the results of rapid urbanization in developed countries, research question of growth has started to be addressed over the concept of sustainability at the global level and has acquired a dimension to include not only the developed countries, but also the developing countries. In developing countries, the extent of demand for growth creates a substantial pressure over governments and environmentally harmful implementations take place. Especially, establishing sustainable growth strategies for cities of the countries that are newly industrializing and, for that purpose, defining the conditions that shape the growth is of vital importance. Cities

Manuscript received January. 22, 2017.

A.N. Albayrak, Department of City and Regional Planning, Gebze Technical University, 41400 Kocaeli Turkey

Y. Eryilmaz, Department of City and Regional Planning, Gebze Technical University, 41400 Kocaeli Turkey are rapidly spreading and destroying the environment in big metropolises with a rapidly rising population and in the settlements in the peripheries of those metropolises. Inadequacies of transportation and technical infrastructure brought by lack of development deepen problems while environmentally damaging speculative investments increase due to unearned income expectation.

The focus of this study is Gebze experiencing the similar. Gebze is an industrial settlement that has been experiencing a rapid economic growth and spatial spreading process within the last 30 years in the periphery of Istanbul Metropolitan Area. In this study, firstly the concept of sustainable urban development is emphasized, and then the development of Gebze settlement is evaluated in this context.

\section{SUSTAINABLE URBAN DEVELOPMENT}

Sustainability includes ecology as well as society and economy. "It is important not only to perceive sustainability as an intersection of society, economy and ecology, but also to see that ecology, for a strong sustainable development, is an indispensable value that contains both society and economy" (see in Fig.1) [2].

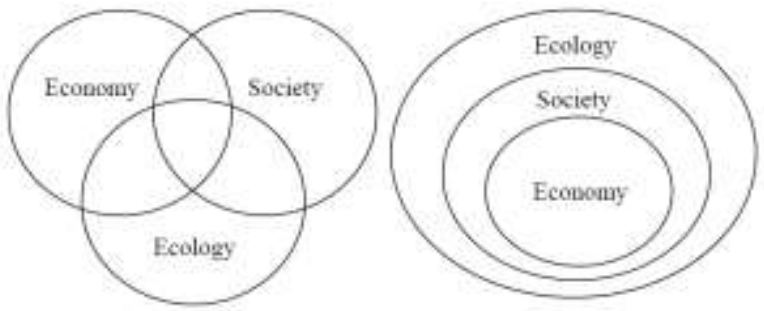

Fig. 1. Sustainable Development [3]-[4]

In today's world where growth is inevitable for cities, the issue emphasized is how the spatial effects of this growth will be minimized. This effort has enabled many approaches to be generated from smart growth to sustainable cities, green cities to low-carbon cities. Sustainable urban development strategies try to find solutions for less natural resource consumption and minimum use of urban areas while the cities sustain their economic developments. For that purpose, many international projects and initiatives for establishing environment-friendly, more livable cities have been put into practice (see in Table I).

In the context of sustainable urban development, there many new urban (planning) approaches have been developed such as green-city, eco-city, livable city, smart city, slow city. These approaches are in a struggle for reaching sustainable human settlements and also more effective sustainable urban planning system. 
TABLE I: INTERNATIONAL ATTEMPT FOR SUSTAINABLE URBAN DEVELOPMENT

\begin{tabular}{ll}
\hline \hline $\begin{array}{l}\text { Year-Period / } \\
\text { Location }\end{array}$ & Event-Activity \\
\hline 1992 / Rio (Brazil) & $\begin{array}{l}\text { Agenda 21 / Local Agenda 21 / UN Conference on } \\
\text { Environment and Development } \\
\text { European Urban Charter I } \\
1992\end{array}$ \\
1994 / Aalborg & European Conference on Sustainable Cities \& \\
(Denmark) & Towns \\
1999 / Potsdam & ESDP-European Spatial Development Perspective \\
2000 & Guiding Principles for Sustainable Spatial \\
$2001-2007$ & Development of the European Continent CEMAT \\
2004 / Aalborg & Sustainable Cities Program UNEP-UN Habitat \\
(Denmark) & Charter of European Cities \& Towns Towards \\
2006 & Sustainability - Aalborg Charter \\
2007 / Leipzig & European Sustainable Development Network \\
2008 & (ESDN) \\
2016 / Quito & Leipzig Charter on Sustainable European Cities \\
(Ecuador) & European Urban Charter II \\
\hline \hline
\end{tabular}

The principles of sustainable planning of a city include "vision, economy and society, biodiversity, ecological footprints, modeling cities on ecosystems, sense of place, empowerment, partnerships, sustainable production and consumption, and governance and hope" [5]. Sustainable urban development basically endeavors to provide the compatibility of urban growth with the environment. This effort includes three dimensions. These are spatial development, socio-economic development and environmental-ecologic values. While spatial development which contains approaches focusing on the urban form addresses urban development mostly within the urban sprawling-compact development dilemma, socio-economic development focuses on targets including production, quality of life, human development and a healthy society. Environmental-ecologic values which holds the priority of the environmental perspective aims to minimize the harm given to the ecosystem and to protect the environmental values. Sustainable urban development is possible with the combination of these three dimensions [2].

\section{Sustainable Urban DeVElopment In TURKeY}

There is an extensive research background and effort for developing policies on interregional development gaps in Turkey. Due to development gaps, some regions face an intensive increase in population and migration, particularly the provinces with developed industry and metropolitan cities, while some regions lose their population. Many problems are experienced in cities within this structure. Inability of the fragmented structure in planning system in Turkey to solve the emerging problems has necessitated the development of a more integrated approach in spatial planning.

In order to produce solution for these problems, KENTGES-Integrated Urban Development Strategy and Action Plan (2010-2023) was announced in 2010. The objective of this plan is the formation of a road map for raising the livability level, space and life quality of settlements and for strengthening the economic, social and cultural structures of settlements for central and local administrations [6]. Within this framework, many responsibilities have been defined for central and local administrations (see in Table II). And providing "sustainable spatial development" in settlements is the most important of them [7].

\section{TABLE II: RESPONSIBILITIES OF LOCAL ADMINISTRATIONS FOR SUSTAINABLE URBAN DEVELOPMENT}

\begin{tabular}{l}
\hline Main subjects \\
\hline Providing sustainable spatial development in the settlement \\
Creating a sustainable urban transportation system \\
Integrating spatial plans and urban infrastructure investments \\
Providing social services and facilities evenly in the settlement \\
Implementing integrated urban regeneration with social, cultural and \\
economic dimensions \\
Decreasing disaster risks in the settlement \\
Protecting and developing urban identity \\
Creating an environmentally sensitive habitat in the settlement \\
Increasing tolerance, cohesion and solidarity in the city and providing \\
services to disadvantageous groups \\
Developing urban culture, urbanity conscious, and sense of belonging \\
Composing awareness on citizen rights \\
\hline \hline
\end{tabular}

\section{Spatial Dimension Of Sustainable Urban DEVELOPMENT}

Spatial development cities take place on cultural and geographical fundamentals. Here, socioeconomic and cultural elements such as income level, life style, automobile possession as well as factors such as climate, topography are also effective. For example, European cities are relatively in a more compact form while US cities have a lower density, widespread texture. These differences in urban macroform are effective on the development of the city. As the city grows in populated area in time; this form changes as well.

In this context, classification presented by Camagni et al. offers a beneficial framework for the analysis of growth dynamics of a city. According to this classification, urban growth takes place in five different forms [8]:

- Infilling: Filling the empty fields within the city

- Extension: Growth of city towards the peripheries of the city

- Linear development: Growth of city along main transportation axes

- Sprawl: Sprawl of urban development, spreading towards periphery and rural areas

- Large scale project: Growth of city with the effect of big public investments such as mass housing areas, industrial zones, highways that shape urban development

Growing structure of a city may include one or several of these types at the same time as well as the differentiation of dominant growing type may also be in question in time. Within this period, social-economic and political developments are effective as well as the topography of the city and natural thresholds. Change of planning concept, investing power of the public or the existence of capital groups to undertake large-scale projects guide the growth strategies of the city as well. This process may take place as a result of a planned growth or automatically within the effect of local dynamics. However, in any case, it is inevitable that these growing types have some advantages and disadvantages in terms of effect on environment. These effects are summarized in the Table III. 
TABLE III: POSITIVE AND NEGATIVE AFFECTS OF URBAN GROWTH TYPES ON ENVIRONMENT

\begin{tabular}{|c|c|c|}
\hline $\begin{array}{l}\text { Types of urban } \\
\text { growth }\end{array}$ & Positive & Negative. \\
\hline Infilling & $\begin{array}{l}\text { Being a preventer for } \\
\text { spreading of urban areas, } \\
\text { ensuring that the current } \\
\text { infrastructure is used } \\
\text { efficiently }\end{array}$ & $\begin{array}{l}\text { Risk of structuring of urban } \\
\text { green areas and spaces, } \\
\text { negative environmental } \\
\text { conditions in terms of wind } \\
\text { and heat }\end{array}$ \\
\hline Extension & $\begin{array}{l}\text { Use of current } \\
\text { infrastructure }\end{array}$ & $\begin{array}{l}\text { Creation of structuring } \\
\text { pressure over surrounding } \\
\text { natural areas }\end{array}$ \\
\hline $\begin{array}{l}\text { Linear } \\
\text { development }\end{array}$ & $\begin{array}{l}\text { Use of an existing } \\
\text { infrastructure }\end{array}$ & $\begin{array}{l}\text { Emergence of areas which } \\
\text { don't commune with city, } \\
\text { difficulties in providing } \\
\text { mass transportation service, } \\
\text { increase in transport costs, } \\
\text { pedestrian transport getting } \\
\text { difficult }\end{array}$ \\
\hline Sprawl & $\begin{array}{l}\text { Low-density qualified } \\
\text { housing zones }\end{array}$ & $\begin{array}{l}\text { Increase in transportation } \\
\text { and infrastructure costs, } \\
\text { encouraging use of private } \\
\text { vehicle }\end{array}$ \\
\hline $\begin{array}{l}\text { Large scale } \\
\text { projects }\end{array}$ & $\begin{array}{l}\text { Providing public support } \\
\text { for extensive projects }\end{array}$ & $\begin{array}{l}\text { Causing usage burdens } \\
\text { which are not projected in } \\
\text { current plans, supporting } \\
\text { land speculation }\end{array}$ \\
\hline
\end{tabular}

When we consider Wheeler's five sustainable design criteria [9] we can evaluate urban growth types (see in Table IV).

The first criterion is compact development which is indispensably compatible with infilling. Some good compact city examples are known in Europe, especially in Germany, Denmark and the Netherlands [10]. Compact urban form is also a design policy at the European Union level [11]-[12]-[13].

The second criterion is contiguous development, which explains well extension type of urban growth. According to contiguous development, new areas emerge as a part of existing urban pattern. Thus, the negative urbanization effects on rural land might be limited.

The third criterion is connected development. Different urban usages or neighborhoods should be connected both physically and perceptively. This connection includes transportation, pedestrian access, bike lines and visual perception. Infilling and extension types of urban growth are closer to sustainable urban development in the context of sustainable design.

Diverse development is the fourth criterion and it is also related to connected development. For a sustainable design, urban districts should include different land-use types, facilities and also socio-economic groups. House-work place balance decrease traffic and provide spatial connectivity. Diversification also helps local administration to deal with social problems such as security, social segregation etc. Linear development and urban sprawl are weak growth types or diversification.

The last criterion is ecological development. Urban growth should consider green-open areas, river basin, wetlands, wind corridors, local landscape etc. Geographical features define which growth type is appropriate for a city.
TABLE IV: URBAN GROWTH TYPES VS SUSTAINABLE DESIGN CRITERIA

\begin{tabular}{|c|c|c|c|c|c|}
\hline & 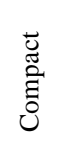 & 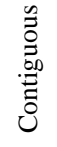 & $\begin{array}{l}\overrightarrow{0} \\
\stackrel{0}{0} \\
0 \\
0 \\
0\end{array}$ & $\begin{array}{l}\text { D. } \\
\stackrel{0}{0} \\
\stackrel{2}{0}\end{array}$ & $\begin{array}{l}\overline{0} \\
.00 \\
00 \\
0 \\
0 \\
0\end{array}$ \\
\hline Infilling & $* * *$ & $* * *$ & **** & $* * *$ & ** \\
\hline Extension & $* *$ & $* *$ & $* *$ & $* *$ & $*$ \\
\hline $\begin{array}{l}\text { Linear } \\
\text { development }\end{array}$ & $*$ & * & $* *$ & * & $* *$ \\
\hline Sprawl & $*$ & $*$ & $*$ & * & * \\
\hline $\begin{array}{l}\text { Large scale } \\
\text { projects }\end{array}$ & $?$ & $?$ & $?$ & $?$ & $?$ \\
\hline
\end{tabular}

\section{Gebze Case: Evaluation Of Growth Process Of GEBZE}

Gebze has a development story that also includes 5 urban growth types described by Camangi [8]. Located in the periphery of Istanbul Metropolitan Area, the settlement has gained a great development speed as a result of industrial decentralization from Istanbul. Although Gebze is administratively located in Kocaeli province (see in Fig.2), it is an industrial city remaining in the hinterlands of Istanbul in terms of economic relations.

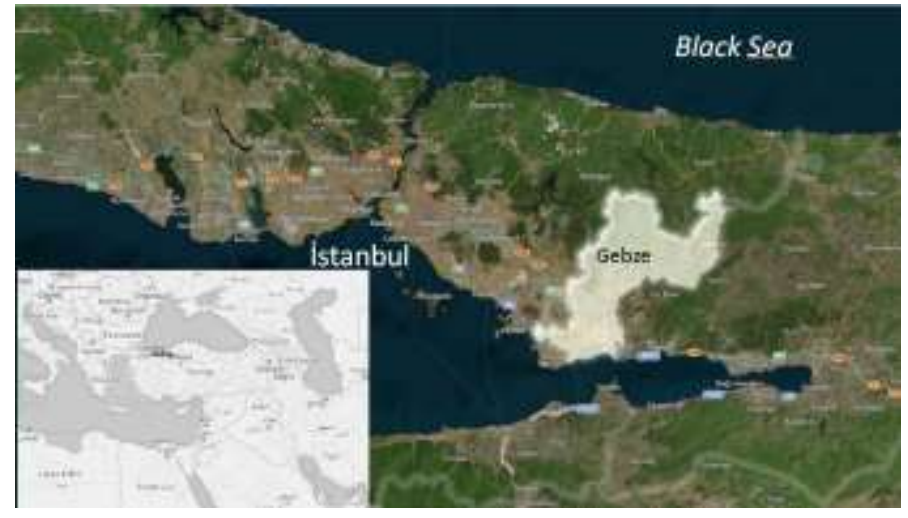

Fig. 2. Location of Gebze [14]-[15]

In fact, urban development in Gebze was realized as a part of industrial decentralization from Istanbul. Foundation of industrial facilities have caused to increase in the population of the city, encouraged migration. Because of this increasing population Gebze become the most populated district in Kocaeli province (see in Fig.3). 


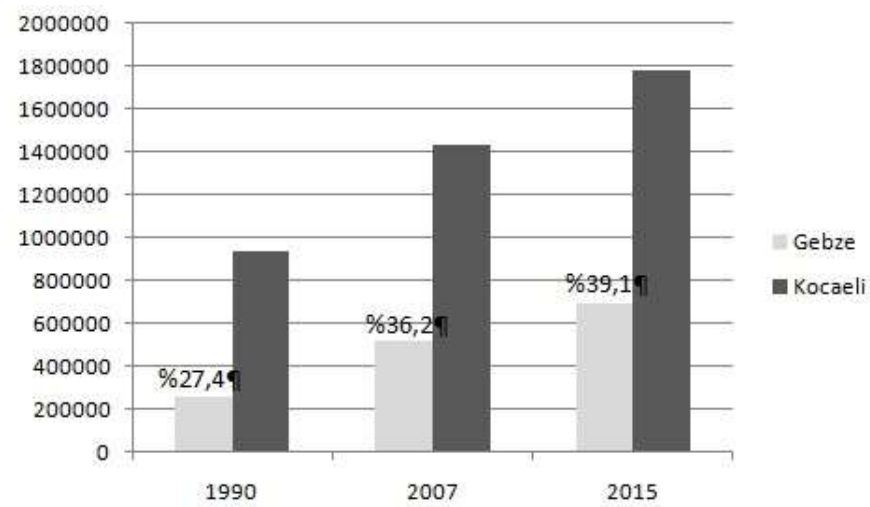

Fig. 3. Share of Gebze population in Kocaeli province [16]

Formation of working class neighborhoods - even shanty houses in some sites - by industrial workers around big plants has determined the development of housing zones of the city. Settlement has, in time, changed into economic - but unqualified - dwellings zones for low-income group working in Istanbul. While today, it is an industrial city open for transformation and development with its large transportation projects, techno parks, advanced industrial facilities (see in Fig.4).

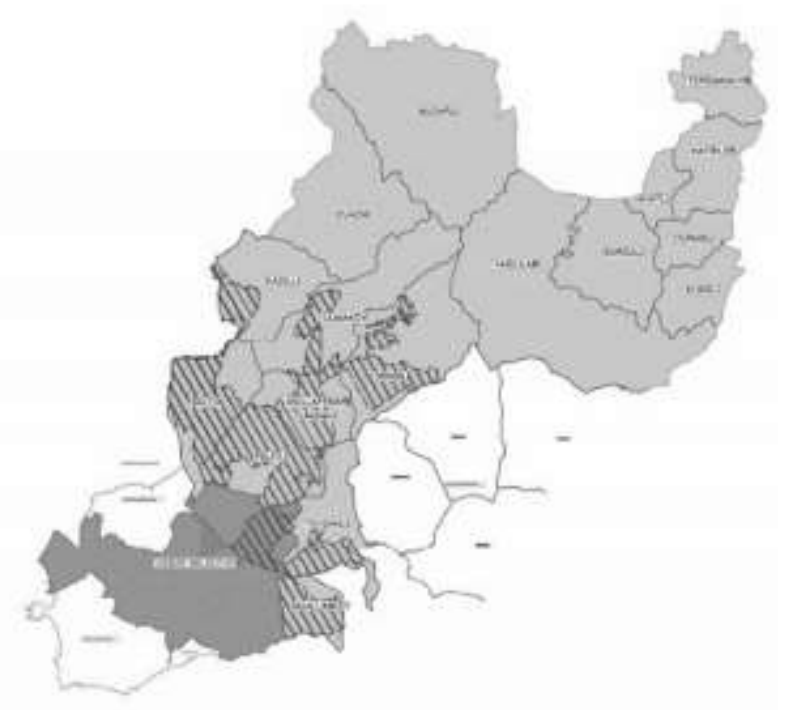

Fig. 4. Planned build-up areas, (village) development zones and rural areas of Gebze [17]

Examination made on urban form in Gebze indicates that different urban growth types have been determinant in historical process. Observed to have made a compact progress in the beginning, the city has first developed linearly in time with the effect of transportation investments of public. As a result of this process where the industrial and residential investments have supported the extension of the city towards periphery, it is seen that the city has gained a sprawling form northwardly.

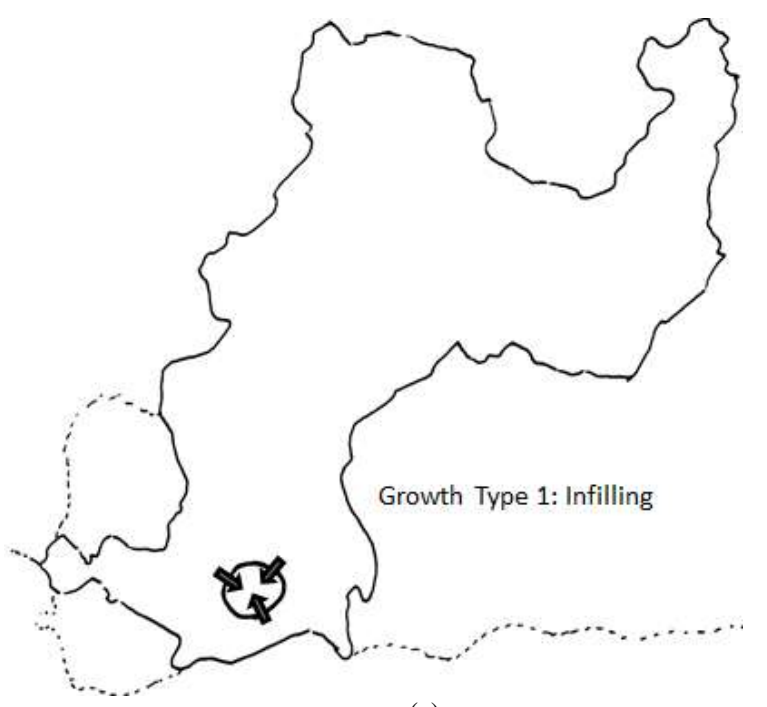

(a)

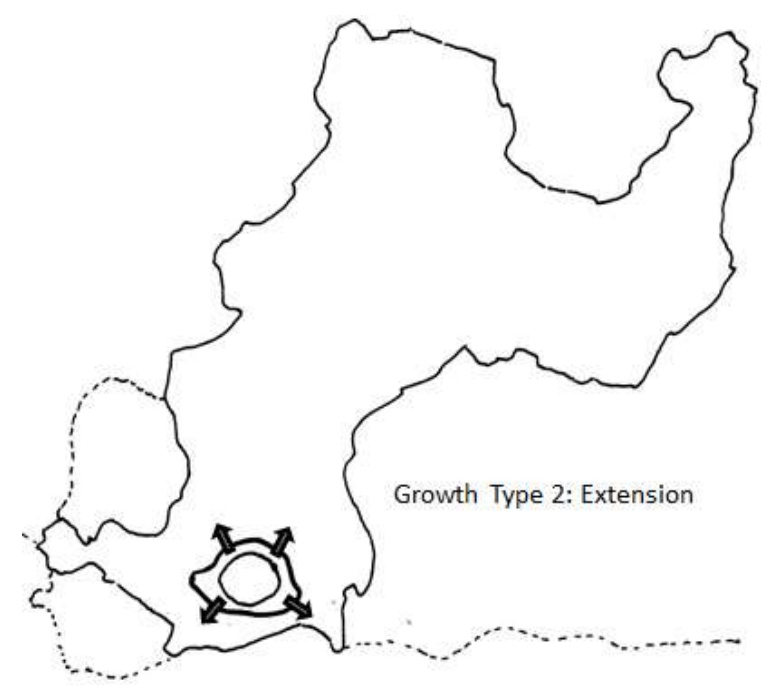

(b)

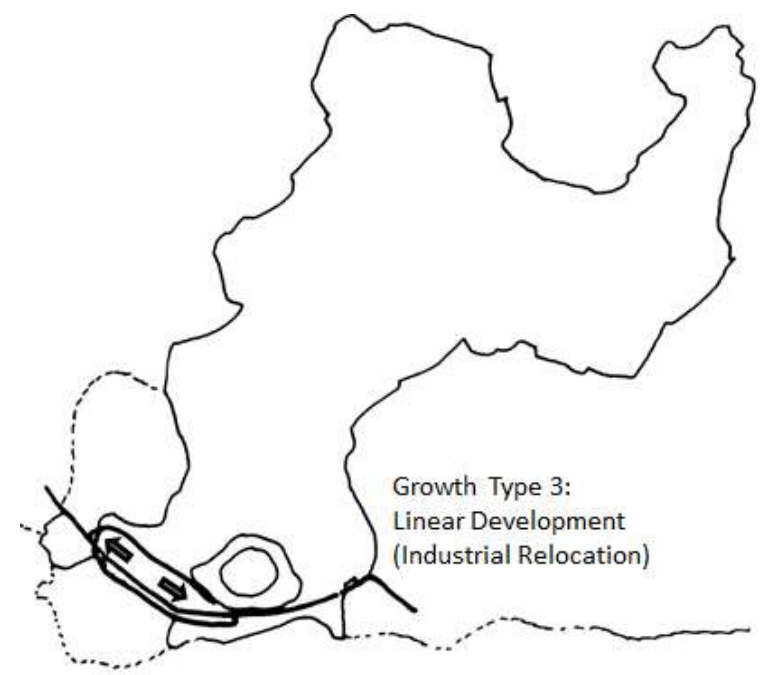

(c) 


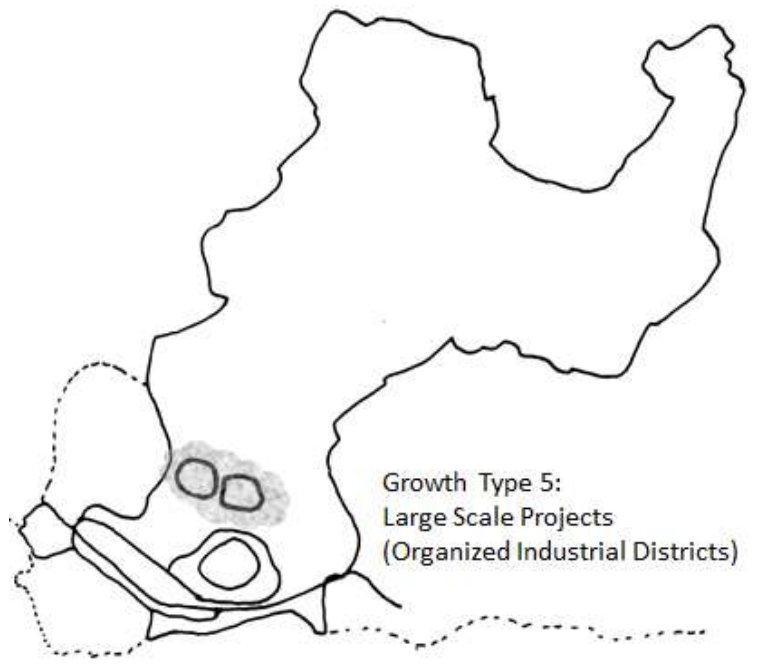

(d)

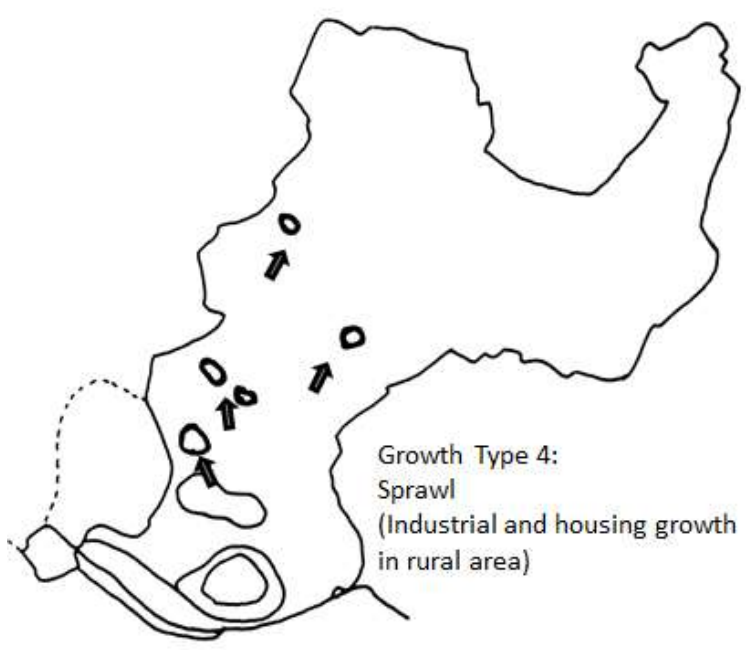

(e)

Fig. 5. Growth stages of Gebze according to growth types

\section{CONCLUSion AND Policy ReCommendations}

It is seen in the model of Gebze that rural areas, agricultural areas and forests surrounding the city are under the pressure of urbanization in the development process of the city. The city grows northward by transforming natural areas. Determination of the stages of this process is important in academic terms as well as being necessary for orientation of developments to satisfy national targets on sustainability. Natural thresholds and optimum service delivery area should be taken into account in growth of city, implementations reducing carbon footprint and making the city ready for the agenda of climate change have to be adopted. For that purpose; mass transportation, pedestrian-bicycle transport have to be encouraged. Green spaces within and around the city have to be protected; housing zones have to be prevented from sprawling out of the city.

In the next studies, focusing on how the developments in Gebze take shape within planning period is aimed. Lack of data is the biggest constraint in the studies of future as well as in this study. It is expected that this lack is overcome by field studies and the spatial development in Gebze is analyzed thoroughly.

\section{REFERENCES}

[1] UN, Our Common Future, 1987.

[2] A. N. Albayrak and N. Senlier, "Industrial Ecology for Sustainable Cities" in Environment and Ecology at the Beginning of $21^{\text {st }}$ Century, R. Efe, C. Bizzarri, I. Curebal, G. N. Nyusupov, Ed, Sofia: St.Kliment Ohridski University Press, 2015, pp. 190-202.

[3] S. Campbell, "Green Cities, Growing Cities, Just Cities?", APA Journal, pp. 296-312, Summer 1996.

[4] PCE, Creating Our Future: Sustainable Development for New Zealand, Office of the Parliamentary Commissioner for the Environment, Wellington, New Zealand, 2002, Available: www.pce.govt.nz

[5] P. Newman and I. Jennings Cities as Sustainable Ecosystems: Principles and Practices, Island Press, USA. 2008.

[6] KENTGES, 2010, Available: http://www.kentges.gov.tr

[7] Ministry of Environment and Urbanization, KENTGES Action Plan (2010-2023), 2010.

[8] R. Camagni, M. C. Gibelli, P. Rigamonti, "Urban mobility and urban form: the social and environmental costs of different patterns of urban expansion", Ecological Economics, vol. 40, pp. 199-216, 2002. https://doi.org/10.1016/S0921-8009(01)00254-3

[9] S. M. Wheeler, "The Evolution of Urban Form in Portland and Toronto: implications for sustainability planning", Local Environment, vol. 8(3), pp. 317-336, 2003. https://doi.org/10.1080/13549830306656

[10] P. J. Marcotullio, "The compact city, environmental transition theory and Asia-Pacific urban sustainable development", International Workshop: New Approaches to Land Management for Sustainable Urban Regions, University of Tokyo, Japan, 29-31 October 2001.

[11] Comission of the European Community, Green Paper on the Urban Environment, Com 90, 27 June, Brussels, 1990.

[12] Comission of the European Community, European Sustainable Cities, A Report from Expert Group on the Urban Environment, March, Brussels, 1996.

[13] Comission of the European Community, Green Paper, Towards a new culture for urban mobility, Com 2007, 25.09, Brussels, 2007.

[14] Available: https://www.bing.com/maps/

[15] Available: https://www.openstreetmap.org/\#map=5/34.198/34.695

[16] TUIK ADNKS database, 2016, Available: www.tuik.gov.tr Gebze Municipality, Dogukan Imar, Plan Report (no date)

Ayse Nur Albayrak was born in Trabzon, Turkey in 1976. She received bachelor's degree on urban and regional planning from Gazi University, Ankara, and master degree from Gebze Institute of Technology, Kocaeli, Turkey. She holds a PhD degree on urban planning from Istanbul Technical University, Turkey. Her major field of study is regional competition and innovativeness.

She worked as a research assistant at Gebze Institute of Technology and Istanbul Technical University. She has been as a researcher in (regional) planning studies in Istanbul, in 2008-2009 and Bursa, in 2010-2012.

Dr. Albayrak, now, works in Gebze Technical University, Kocaeli, Turkey. She has various studies about sustainability, eco-industrial parks, urban growth, regional policies and innovativeness.

Yasasin Eryilmaz was born in Burdur, Turkey, in 1970. He received bachelor's degree on urban and regional planning from Istanbul Technical University, and master degree from Gebze Institute of Technology, Kocaeli, Turkey. He holds a $\mathrm{PhD}$ degree on transportation engineering from Istanbul Technical University. His major field of study is urban transportation and urban planning

He worked as a research assistant at Gebze Institute of Technology and Istanbul Technical University. He has been as a researcher in transportation planning studies in Istanbul, in 2016-2017.

Dr. Eryilmaz now, works in Gebze Technical University, Kocaeli, Turkey. He has various studies about transportation planning, urban growth, urban economics, regional policies and issues related to the field of planning. 